\title{
Synthesis of Some Polyamides from Bis(thiosemicarbazone)acenaphthenequinone
}

\author{
NAVABEH NAMI ${ }^{\mathrm{a}^{*}}$, HOSSEIN MIGHANI ${ }^{\mathrm{b}^{*}}$, \\ NAJMEH KIA $^{\mathrm{a}}$ and HAMED SADATFARAJI ${ }^{\mathrm{b}}$
}

${ }^{\mathrm{a}}$ Department of Chemistry, Qaemshahr Branch, Islamic Azad University, Qaemshahr, Mazandaran Iran

${ }^{\mathrm{b}}$ Department of Chemistry, University of Golestan, Gorgan, Iran

Navabehnami@yahoo.com

Received 5 June 2012 / Accepted 22 June 2012

\begin{abstract}
Bis(thiosemicarbazone)acenaphthenequinon $\left(\mathrm{LH}_{6}\right)$ was synthesized in one step from acenaphthoquinone and thiosemicarbazone. The diamine $\left(\mathrm{LH}_{6}\right)$ was characterized by FT-IR, ${ }^{1} \mathrm{H}$ NMR and melting point. diamine was used to prepare novel polyamides. The low temperature solution polycondensation of ligand with aromatic ring. Diacid chlorides and high temperature polycondensation with dicarboxylic acid afforded ligand-containing polyamides with inherent viscosities of $0.31-0.38 \mathrm{dL} / \mathrm{g}$ in $N$-methylpyrolidone at $25^{\circ} \mathrm{C}$. The polyamides were generally soluble in a wide range of solvents such as dimethyformamide(DMF), $N$-Methylpyrolidone(NMP), dimthylsulfoxide (DMSO) and $\mathrm{H}_{2} \mathrm{SO}_{4}$. Thermal analysis showed that these polyamides were practically amorphous and exhibited $10 \%$ weight loss at and above $220^{\circ} \mathrm{C}$.
\end{abstract}

Keywords: Polyamides, Thermalstability, Bisthiosemicarbazone, Acenaphthoquinone, Diacide

\section{Introduction}

Polyamides, the most versatile class of engineering polymers, display a wide range of properties. Aliphatic polyamides find many industrial and textile applications due to their high mechanical strength and durability. Many studies on polyamides have been reported previously $^{1-6}$. Aromatic polyamides (aramids) are being used in industry because of their outstanding properties. However, poor solubility in common organic solvents and high melting temperatures are the limiting factors for the processing of these materials. A lot of attempts have been made to solubilize these polymers in order to prepare their composites using different techniques ${ }^{7-11}$. Aliphatic-aromatic polyamides (glass clear nylons) offer a wide range of properties including transparency, thermal stability, good barrier and solvent resistant properties. These commercial polyamides have been reinforced with various ceramic phases ${ }^{12-15}$. There are numerous references to polyamides from aliphatic diamines and aromatic diacids and a far lesser number to polyamides from aromatic diamines and aliphatic diacids ${ }^{16-24}$. Probably the reason that aliphatic-aromatic polyamides have been studied 
in greater detail than the aromatic-aliphatic is that many of the former group can be made by melt and plasticized melt methods ${ }^{18,19,25}$ or by standard interfacial procedures ${ }^{21,23,26}$. The aromatic- aliphatic polyamides, on the other hand are difficult to prepare by interfacial and solution methods ${ }^{16,27}$ and when prepared by melt methods, frequently are discolored and may have branched or network structures. In the other hand, polymers with a system of conjugated $\mathrm{C}=\mathrm{C}$ - and $-\mathrm{C}=\mathrm{N}$ - bonds in their main chain have been drawing the attention of researchers because of their importance in many areas ${ }^{28-32}$. Among these polymers, polyamides, which are characterized by the presence of $\mathrm{HC}=\mathrm{N}$ linkages, are of considerable interest and are produced by the polycondensation of diamines with various dicarbonyl compounds. They have thermal stability similar to that of polyamides and have been used as solid stationary phases for gas chromatography ${ }^{33}$. The high thermal stability of fully aromatic polyamides is due to the great number of aromatic rings and the extent of electronic conjugation over the entire molecule, which lead to polymers with high conducting properties. To lower the transition temperatures and to improve the solubility, several methods are used, such as copolymerization and the introduction of bulky alkyl, alkoxy, or aryl groups into the aromatic rings or into the polymer backbone $^{32,34}$. In this article, we report the synthesis of new polyamides with pendant bulky aryl groups containing by the low-temperature polycondensation reaction of diacid chlorides such as terephthaloyl dichloride, isophthaloyl dichloride, sebacoyl dichloride, adipoyl dichloride, and succinoyl dichloride with a new diamine, bis(thiosemicarbazone)acenaphthenequinone $\left(\mathrm{LH}_{6}\right)$. The physical properties of the polymers, including the characterization, inherent viscosity (hinh), solubility and thermal properties, are also reported. We will also report other properties of these polyamides in a future publication.

\section{Experimental}

acenaphthoquinone, thiosemicarbazide and other reagents and solvents were purchased from Fluka and used without purification. ${ }^{1} \mathrm{H}$ NMR spectra were recorded on a $500 \mathrm{MHz}$ Bruker Advance DRX instrument using DMSO- $\mathrm{d}_{6}$ as solvent and tetramethylsilane as an internal standard. FT-IR spectra were recorded using a Bruker Vector 22 spectrometer on $\mathrm{KBr}$ pellets. The CHN- 600 Leco analyzer was used for elemental analysis. Thermal gravimetric analysis (TGA) and differential scanning calorimetry (DSC) analysis were performed using Perkin-Elmer Pyris and Metler Tolledo $822^{\mathrm{e}}$, respectively. Inherent viscosity $\left(\eta_{\text {inh }}=\mathrm{Ln} \eta_{\text {rel }} / \mathrm{C}\right)$ of polymers were determined for solution of $0.5 \mathrm{~g} / \mathrm{dL}$ in NMP at $25^{\circ} \mathrm{C}$ using an Ubbelohde Viscometer. Total sulfur was measured using Tanaka Model RX-360 SH.

\section{Preparation of monomers}

\section{Bis(thiosemicarbazone) acenaphthenequinone $\left(\boldsymbol{L H}_{\mathbf{6}}\right)$}

The thiosemicarbazide $(3.64 \mathrm{~g}, 40.30 \mathrm{mmol})$ and acenaphthoquinone (3.64 g, $20.20 \mathrm{mmol})$ were added in $40 \mathrm{~mL}$ of ethanol, $40 \mathrm{~mL}$ of $2 \mathrm{~N} \mathrm{HCI}$ and $1 \mathrm{~mL}$ of conc. $\mathrm{HCl}$. The mixture was stirred for $10 \mathrm{~h}$ under reflux condition. After cooling the reaction, the yellow solid was filtered off, washed with ethanol and dried in a vacuum oven at $70{ }^{\circ} \mathrm{C}$ for $2 \mathrm{~h}$. A yellow solid product was obtained in a $70 \%$ yield which starts to melt and decompose at $250{ }^{\circ} \mathrm{C}$.

IR $(\mathrm{KBr})\left(v_{\max } \mathrm{cm}^{-1}\right): 3440(\mathrm{NH}), 3250\left(\mathrm{NH}_{2}\right), 3050(\mathrm{C}-\mathrm{H}$ aromatic ring), 1598(CN), 1479 $\left(\mathrm{C}=\mathrm{C}_{\mathrm{Ar}}\right), 823(\mathrm{CS}) .{ }^{1} \mathrm{H}$ NMR (400, DMSO, d6, TMS $) \delta \mathrm{ppm}: 4.2(1 \mathrm{H}, \mathrm{S}, \mathrm{NH}), 5.28(1 \mathrm{H}, \mathrm{S}, \mathrm{SH})$, 5.75(2H, S, $\left.\mathrm{NH}_{2}\right), 7.8-7.9\left(3 \mathrm{H}, \mathrm{m}, \mathrm{CH}_{\mathrm{Ar}}\right), 8.0\left(2 \mathrm{H}, \mathrm{t}, \mathrm{CH}_{\mathrm{Ar}}\right), 8.38\left(1 \mathrm{H}, \mathrm{d}, \mathrm{CH}_{\mathrm{Ar}}\right), 12.93(1 \mathrm{H}, \mathrm{S}$,

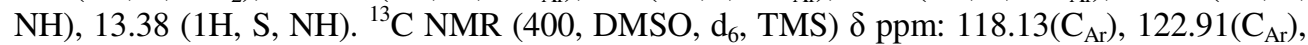
127.28 $\left(\mathrm{C}_{\mathrm{Ar}}\right), 129.08\left(\mathrm{C}_{\mathrm{Ar}}\right), 133.39\left(\mathrm{C}_{\mathrm{Ar}}\right), 140.18\left(\mathrm{C}_{\mathrm{Ar}}\right), 55.07(\mathrm{C}=\mathrm{N}), 165.94(\mathrm{C}=\mathrm{S})$. Anal. Calcd. For $\left[\mathrm{C}_{14} \mathrm{H}_{12} \mathrm{~N}_{6} \mathrm{~S}_{2}\right]$ : C, 51.22; H, 3.65; N, 25.6. Found: C, 50.87; H, 3.87; N, 26.23. 


\section{Preparation of polyamides}

\section{General procedure}

A typical procedure for the preparation of polyamides is given in Scheme 2. A two-necked flask equipped with a dropping funnel and gas inlet tube was charged with a mixture of $\mathrm{LH}_{6}(0.712 \mathrm{~g}, 2 \mathrm{mmol}), 20 \mathrm{~mL}$ dimethylformamide (DMF) and triethylamine $(0.8 \mathrm{~mL})$. Diacid chloride (DC) $(2 \mathrm{mmol})$ dissolved in $20 \mathrm{~mL}$ DMF was added drop wise to the stirred solution at $0{ }^{\circ} \mathrm{C}$ under $\mathrm{N}_{2}$. The mixture was subsequently stirred at ambient temperature for $3 \mathrm{~h}$ under $\mathrm{N}_{2}$ and then it was poured into cold water. The yellow solid product was separated by filtration and washed with $\mathrm{NaHCO}_{3}$ solution. Then the red solid product dried in vacuum oven at $70{ }^{\circ} \mathrm{C}$. A purified sample was obtained by using a Soxhlet extraction system from methanol for $24 \mathrm{~h}$.

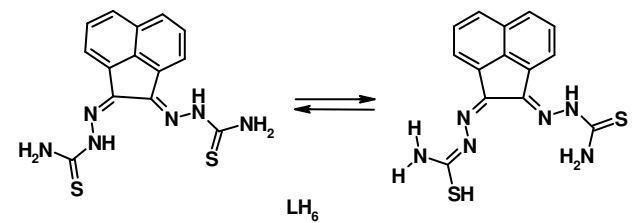

Scheme 1. Structure of ligand

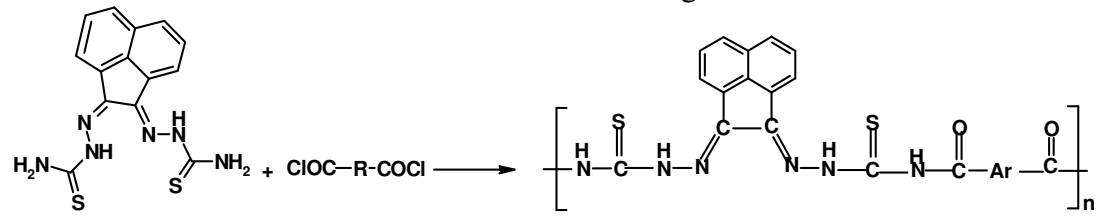

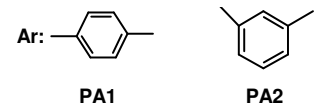<smiles>CC(C)NC(=S)N/N=C1/C(=NNC(=S)NC(=O)CCC(=O)O)c2cccc3cccc1c23</smiles>

Scheme 2. The typical procedure for the preparation of polyamides

\section{Poly [acenaphthenequinone bis(thiosemicarbazone)terephthalate] (PA1)}

Yield 92\%, mp $262{ }^{\circ} \mathrm{C}$, IR $(\mathrm{KBr})\left(v_{\max } \mathrm{cm}^{-1}\right): 3423(\mathrm{~N}-\mathrm{H}), 3300(\mathrm{~N}-\mathrm{H}), 3000(\mathrm{C}-\mathrm{H}$ aromatic), $1684(\mathrm{C}=\mathrm{O}), 1630(\mathrm{C}=\mathrm{N}), 1596\left(\mathrm{C}=\mathrm{C}_{\mathrm{Ar}}\right),{ }^{1} \mathrm{H}$ NMR (400, DMSO, $\left.\mathrm{d}_{6}, \mathrm{TMS}\right) \delta \mathrm{ppm}: 7.84,7.89$ $\left(2 \mathrm{H}, \mathrm{m}, \mathrm{CH}_{\mathrm{Ar}}\right), 8,8.11\left(2 \mathrm{H}, \mathrm{m}, \mathrm{CH}_{\mathrm{Ar}}\right), 8.1,8.29\left(4 \mathrm{H}, \mathrm{m}, \mathrm{CH}_{\mathrm{Ar}}\right), 8.31,8.38\left(1 \mathrm{H}, \mathrm{m}, \mathrm{CH}_{\mathrm{Ar}}\right)$, 8.4 $\left(1 \mathrm{H}, \mathrm{CH}_{\mathrm{Ar}}\right), 8.69(1 \mathrm{H}, \mathrm{S}, \mathrm{NH}), 8.9(1 \mathrm{H}, \mathrm{S}, \mathrm{NH}), 12.26(1 \mathrm{H}, \mathrm{S}, \mathrm{NH}), 12.91(1 \mathrm{H}, \mathrm{S}, \mathrm{NH})$. Anal. Cald. For $\left[\mathrm{C}_{22} \mathrm{H}_{14} \mathrm{~N}_{6} \mathrm{O}_{2}\right]$ : C, 57.64; H, 3.05; N, 18.34. Found: C, 56.89; H, 3.25; N, 18.67.

\section{Poly [acenaphthenequinone bis(thiosemicarbazone)isophthalate] (PA2)}

Yield 90\%, mp $265{ }^{\circ} \mathrm{C}$, IR (KBr) $\left(v_{\max } \mathrm{cm}^{-1}\right): 3246(\mathrm{~N}-\mathrm{H}), 3153(\mathrm{~N}-\mathrm{H}), 1640(\mathrm{C}=\mathrm{O}), 1593$ $(\mathrm{C}=\mathrm{N}), 1476(\mathrm{C}=\mathrm{C}$ aromatic $)$. Anal. Cald. For $\left[\mathrm{C}_{22} \mathrm{H}_{14} \mathrm{~N}_{6} \mathrm{O}_{2}\right]: \mathrm{C}, 57.64 ; \mathrm{H}, 3.05 ; \mathrm{N}, 18.34$. Found: C, 56.89; H, 3.25; N, 18.67 . 


\section{Poly [acenaphthenequinone bis(thiosemicarbazone)succinate] (PA3)}

Yield 91\%, mp $255{ }^{\circ} \mathrm{C}$, IR (KBr) $\left(v_{\max } \mathrm{cm}^{-1}\right): 3253(\mathrm{~N}-\mathrm{H}), 3175(\mathrm{~N}-\mathrm{H}), 2900\left(\mathrm{C}-\mathrm{H}_{\text {Aliphatic }}\right)$, $1717(\mathrm{C}=\mathrm{O}), 1595(\mathrm{C}=\mathrm{N}), 1478\left(\mathrm{C}=\mathrm{C}_{\mathrm{Ar}}\right),{ }^{1} \mathrm{H}$ NMR $\left(400, \mathrm{DMSO}, \mathrm{d}_{6}, \mathrm{TMS}\right) \delta \mathrm{ppm}: 3.06,3.09$ $\left(2 \mathrm{H}, \mathrm{t}, \mathrm{CH}_{2}\right), 3.13,3.14(2 \mathrm{H}, \mathrm{t}, \mathrm{CH} 2), 7.91,7.99\left(3 \mathrm{H}, \mathrm{m}, \mathrm{CH}_{\mathrm{Ar}}\right), 8,8.11\left(1 \mathrm{H}, \mathrm{m}, \mathrm{CH}_{\mathrm{Ar}}\right), 8.15$, $816\left(1 \mathrm{H}, \mathrm{d}, \mathrm{CH}_{\mathrm{Ar}}\right), 10.4,12.4(4 \mathrm{H}, \mathrm{S}, \mathrm{NH})$. Anal. Cald. for $\left[\mathrm{C}_{18} \mathrm{H}_{14} \mathrm{~N}_{6} \mathrm{O}_{2}\right]: \mathrm{C}, 52.68 ; \mathrm{H}, 3.41$; N, 20.48. Found: C, 53.23; H, 3.25; N, 20.27.

\section{Poly [acenaphthenequinone bis(thiosemicarbazone)adipoate] (PA4)}

Yield 94\%, mp $252{ }^{\circ} \mathrm{C}$, IR (KBr) $\left(v_{\max } \mathrm{cm}^{-1}\right): 3257(\mathrm{~N}-\mathrm{H}), 3100(\mathrm{~N}-\mathrm{H}), 2800\left(\mathrm{C}-\mathrm{H}_{\text {Aliphatic }}\right)$, $1685(\mathrm{C}=\mathrm{O}), 1601(\mathrm{C}=\mathrm{N}), 1489\left(\mathrm{C}=\mathrm{C}_{\mathrm{Ar}}\right)$. Anal. Cald. for $\left[\mathrm{C}_{20} \mathrm{H}_{18} \mathrm{~N}_{6} \mathrm{O}_{2}\right]$ : C, 54.79; $\mathrm{H}, 4.11$; N, 19.17. Found: C, 55.27; H, 3.87; N, 19.93.

\section{Poly [acenaphthenequinone bis(thiosemicarbazone)sebacoilate] (PA5)}

Yield 85\%, mp $250{ }^{\circ} \mathrm{C}, \mathrm{IR}(\mathrm{KBr})\left(\mathrm{v}_{\max } \mathrm{cm}^{-1}\right): 3430(\mathrm{~N}-\mathrm{H}), 3248(\mathrm{~N}-\mathrm{H}), 2926$ (C-H aliphatic), 1685 $(\mathrm{C}=\mathrm{O}), 1599(\mathrm{C}=\mathrm{N}), 1488\left(\mathrm{C}=\mathrm{C}_{\mathrm{Ar}}\right),{ }^{1} \mathrm{H}$ NMR $\left(400, \mathrm{DMSO}, \mathrm{d}_{6}, \mathrm{TMS}\right) \delta \mathrm{ppm}: 1.65,1.68(3 \mathrm{H}, \mathrm{t}$, $\left.\mathrm{CH}_{2}\right), 2.16,2.19(2 \mathrm{H}, \mathrm{t}, \mathrm{CH} 2), 2.56(1 \mathrm{H}, \mathrm{S}, \mathrm{CH} 2), 2.81\left(2 \mathrm{H}, \mathrm{CH}_{2}\right), 7.74,7.77\left(3 \mathrm{H}, \mathrm{m}, \mathrm{CH}_{\mathrm{Ar}}\right), 7.85$, $7.87\left(1 \mathrm{H}, \mathrm{d}, \mathrm{CH}_{\mathrm{Ar}}\right), 7.99,8.01\left(2 \mathrm{H}, \mathrm{t}, \mathrm{CH}_{\mathrm{Ar}}\right), 8.59(1 \mathrm{H}, \mathrm{S}, \mathrm{NH}), 11.23(1 \mathrm{H}, \mathrm{S}, \mathrm{NH}), 12.51(1 \mathrm{H}, \mathrm{S}, \mathrm{NH})$. Anal. Cald. for $\left[\mathrm{C}_{20} \mathrm{H}_{26} \mathrm{~N}_{6} \mathrm{O}_{2}\right]$ : C, 58.29; H, 5.26; N, 17. Found: C, 57.89; H, 5.62; N, 17.41.

\section{Results and Discussion}

The monomer, $\mathrm{LH}_{6}$, was prepared according to the procedures given in the literature. The chemical structure of $\mathrm{LH}_{6}$ is shown in Scheme 1. IR, ${ }^{1} \mathrm{H}$ NMR and elemental analysis data for the $\mathrm{LH}_{6}$ of the present study are in good agreement with the structure. The IR spectra of this compound showed the $\mathrm{NH}$ and $\mathrm{NH}_{2}$ asymmetric and symmetric stretching in $3250-3440 \mathrm{~cm}^{-1}$, $\mathrm{C}=\mathrm{N}$ in $1598 \mathrm{~cm}^{-1}$ and $\mathrm{C}=\mathrm{C}$ in $1479 \mathrm{~cm}^{-1} .{ }^{1} \mathrm{H} \mathrm{NMR}$ showed $\mathrm{NH}_{2}$ protons in $5.75 \mathrm{ppm}$ and three exchangeable protons of $\mathrm{NH}$ in 4.2, 12.93 and $13.38 \mathrm{ppm}$, one $\mathrm{SH}$ proton in $5.28 \mathrm{ppm}$.

The polyamides (PA1- PA5) were synthesized by direct polycondensation of aromatic and aliphatic diacid chlorides (Scheme 2) with $\mathrm{LH}_{6}$ using triethylamine as catalyst. The reactions were carried out in dimethyl formamide solution of the diacid chloride and $\mathrm{LH}_{6}$ in a nitrogen atmosphere and at room temperature. The polymerizations proceeded in homogeneous solution and the yields of the polyamides were quantitative. The elemental analysis values of all the polyamides were generally in good agreement with the calculated values of proposed structures. As representative example, the complete elemental analysis of PA1 was as follows: C, $57.89 \%$ (57.64\% calculated); H, 3.25\% (3.05\%); N, 18.67\% (18.34\%).

The polyamides were also characterized by IR and NMR spectrometers. The IR Spectra of PA1 showed amide bands at ca. $3423 \mathrm{~cm}^{-1}$ (N-H stretching), $1684 \mathrm{~cm}^{-1}$ (C=O stretching) and ca. $1630 \mathrm{~cm}^{-1}(\mathrm{C}=\mathrm{N}$ stretching $)$.

The limiting viscosity number $[\eta]$ of polyamides was determined for extracted and dried polymers in DMF, depending on the solubility of the polyamide. For the same or similar type of linear polymers the $[\eta]$ value is proportional to the molecular mass. The inherent viscosities of polyamides (PA1-PA4), obtained in $\mathrm{N}$-methylpyrrolidone were in the range of $0.25-0.34 \mathrm{dL} / \mathrm{g}$ that revealed reasonable molecular weights (Table 1 ).

One of the major objectives of this study was producing modified polyamides with improved solubility. The solubility of these polyamides was determined for the powdery samples in excess solvents and the results are listed in Table 2. All the polyamides were readily soluble in common polar aprotic solvents without need for heating. Also, by heating 
they were soluble in a less efficient solvent such as THF. The good solubility behavior of most prepared polyamides can be explained through the enhancement of solubility induced by the phenylene groups of the diacid chlorides moiety.

Table 1. Thermal analysis, viscosity and yield of the polyamides

\begin{tabular}{ccccccc}
\hline Compd code & $\mathrm{T}_{\mathrm{g}}$ & $\mathrm{T}_{10 \%},{ }^{\circ} \mathrm{C}^{\mathrm{a}}$ & $\mathrm{T}_{50 \%},{ }^{\circ} \mathrm{C}^{\mathrm{b}}$ & $\%$ Ch. Y. ${ }^{\mathrm{c}}$ & $\eta_{\text {inh }} \mathrm{dL} / \mathrm{g}^{\mathrm{d}}$ & Yield, \% \\
\hline $\mathrm{LH}_{6}$ & - & - & -- & -- & 0.04 & 70 \\
PA1 & 92 & 250 & 430 & 38 & 0.32 & 92 \\
PA2 & - & - & - & - & 0.31 & 91 \\
PA3 & 120 & 240 & 560 & 42.5 & 0.34 & 95 \\
PA4 & - & - & - & - & 0.25 & 94 \\
PA5 & - & 240 & 430 & 42.5 & & \\
\hline
\end{tabular}

${ }^{a} 10 \%$ weight loss, ${ }^{b} 50 \%$ weight loss, ${ }^{c}$ Char yield percent at $600{ }^{\circ} \mathrm{C}$, obtained from $\mathrm{TGA},{ }^{d}$ Measured in $N$-methylpyrrolidone at $25^{\circ} \mathrm{C}(c=0.5 \mathrm{~g} / \mathrm{dL})$

Table 2. Solubility of polyamides

\begin{tabular}{|c|c|c|c|c|c|c|c|c|c|c|c|}
\hline $\begin{array}{l}\text { Polym. } \\
\text { Code }\end{array}$ & NMP & DMF & DMSO & TCE & THF & $\mathrm{H}_{2} \mathrm{SO}_{4}$ & HMPA & DMAC & Aceton & Ethanol & $1 \mathrm{CHCl}_{3}$ \\
\hline $\mathrm{LH}_{6}$ & + & + & + & \pm & + & + & + & + & - & \pm & \pm \\
\hline PA1 & + & + & + & \pm & + & + & + & + & - & \pm & \pm \\
\hline PA2 & + & + & + & \pm & + & + & + & + & - & \pm & \pm \\
\hline PA3 & + & + & + & \pm & + & + & + & + & - & \pm & \pm \\
\hline PA4 & + & + & + & \pm & + & + & + & + & - & \pm & \pm \\
\hline PA5 & + & + & + & \pm & + & + & + & + & - & \pm & \pm \\
\hline
\end{tabular}

Soluble (+), partially soluble ( \pm ), insoluble (-), Solubility tested with $0.5 \mathrm{~g}$ of polymer in $100 \mathrm{~mL}$ of solvent., $N M P=N$-methylpyrrolidone, $D M F=$ dimethylformamide, DMSO=dimetylsolfoxide, TCE = tetrachloroethane, $P y=$ pyridine,$T H F=$ tetrahydrofurane, $H M P A=$ hexamethylenphosphoramide, $D M A C=$ dimethylacetamide

Thermal properties of the prepared polyamides were evaluated by means of DSC and TGA. Representative DSC thermograms of PA1, PA3 and PA5 are shown in Figures 1-3. The DSC scan up to $300{ }^{\circ} \mathrm{C}$ of PA1 and PA3 showed strong exothermic peaks at $251{ }^{\circ} \mathrm{C}$ with glass transition of these polymers at $186^{\circ} \mathrm{C}$ and $240{ }^{\circ} \mathrm{C}$, respectively.

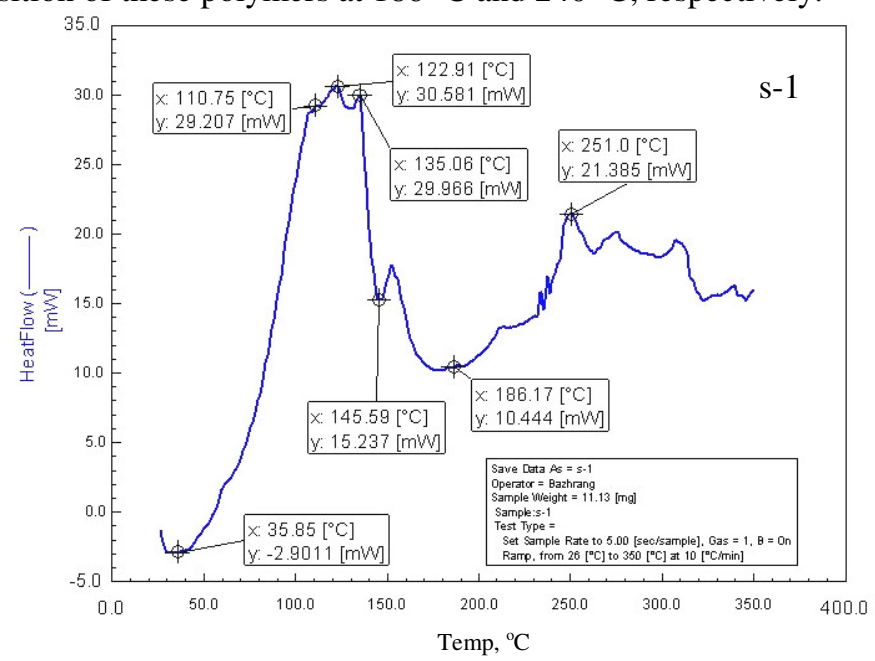

Figure 1. DSC of PA1 


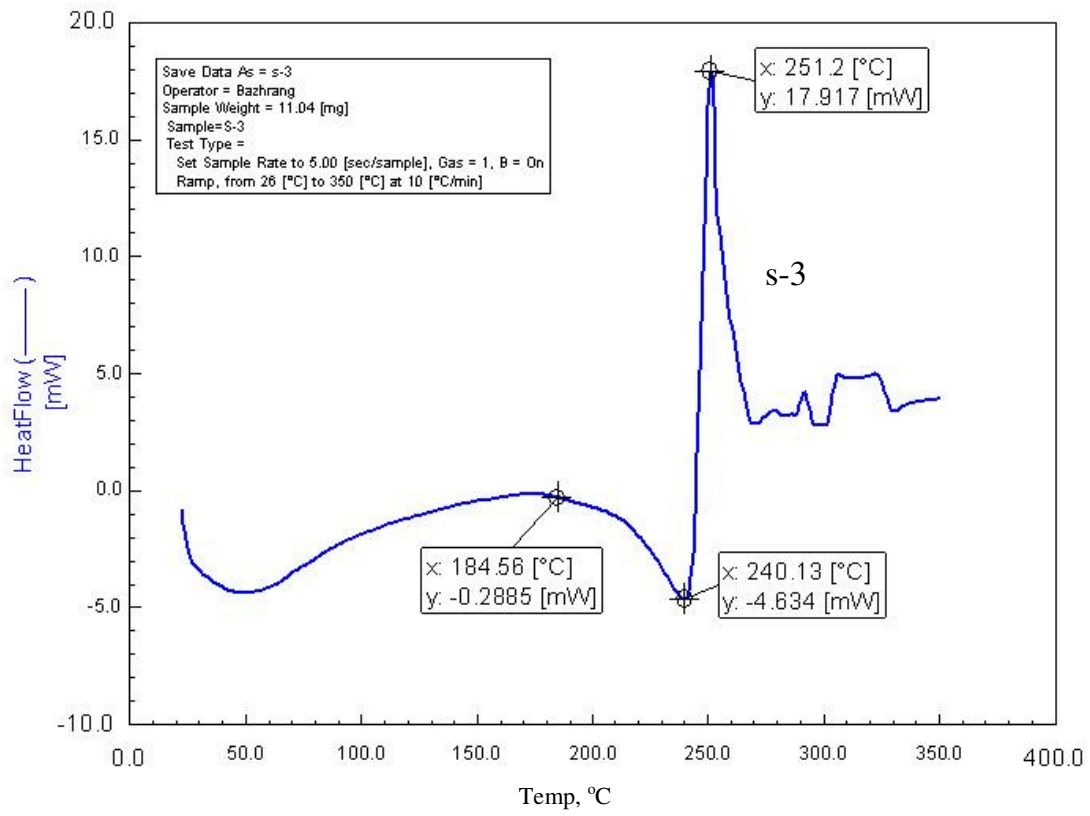

Figure 2. DSC of PA3

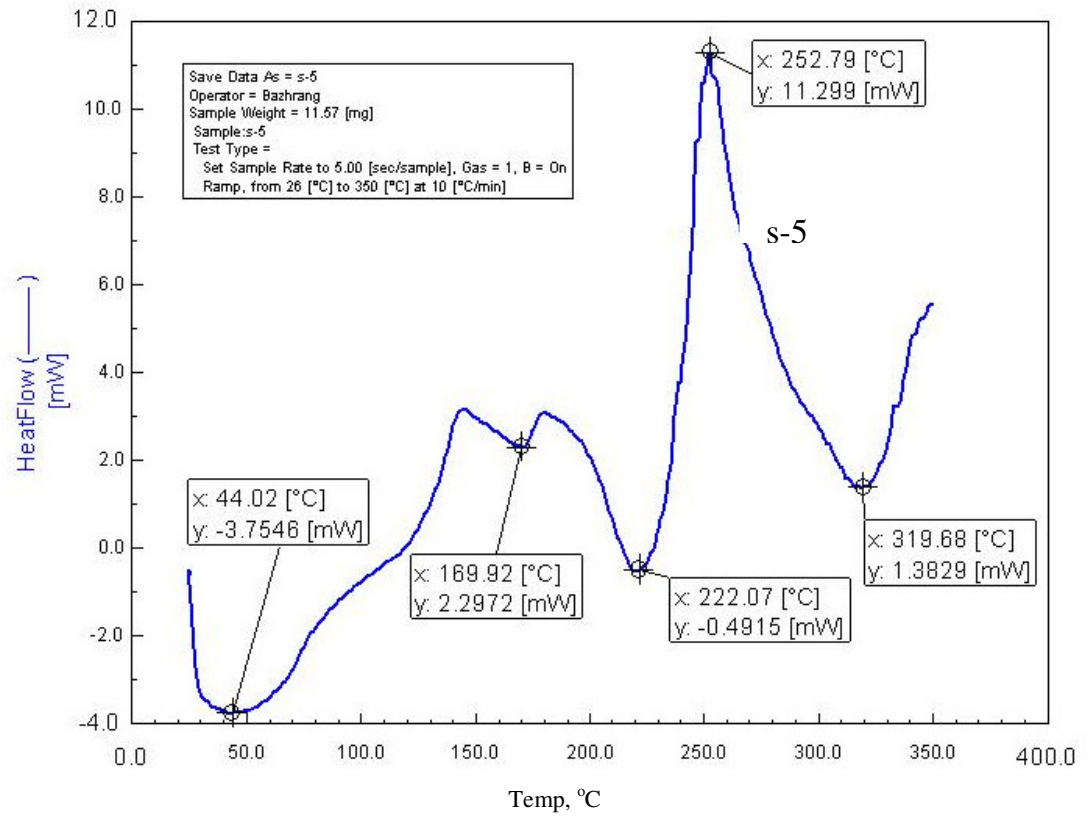

Figure 3. DSC of PA5

The thermal stability of polyamides was also evaluated by TGA. The temperatures of the $10 \%$ and $50 \%$ weight loss and the remained polyamides at $600{ }^{\circ} \mathrm{C}$ in nitrogen atmosphere were given in Table 1 . 
The representative TGA curves are shown in Figures 4-6. All the polymers were stable up to $200{ }^{\circ} \mathrm{C}$ in nitrogen and show almost the same stability. We found that these polyamides did not show obvious weight losses until the temperature reached $200{ }^{\circ} \mathrm{C}$ in nitrogen, implying that no thermal decomposition occurred. However, as the temperature over $200{ }^{\circ} \mathrm{C}$, the polymers showed a rapid thermal decomposition. The $50 \%$ weight losses of PA1 and PA5 were in temperature range of $430{ }^{\circ} \mathrm{C}$. It was $560{ }^{\circ} \mathrm{C}$ in PA3. The polyamides (PA3, PA5) remained $42.5 \%$ of the original weight at $600{ }^{\circ} \mathrm{C}$ in nitrogen; the polyamide (PA1) remained $38 \%$ of the original weight at $600{ }^{\circ} \mathrm{C}$ in nitrogen.

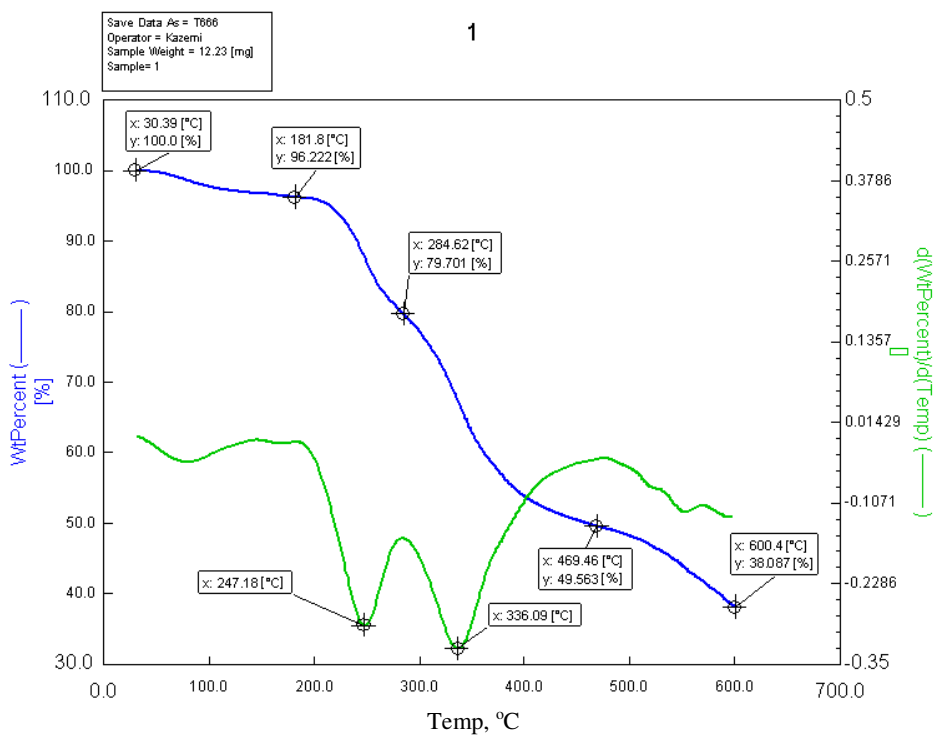

Figure 4. TGA of PA1

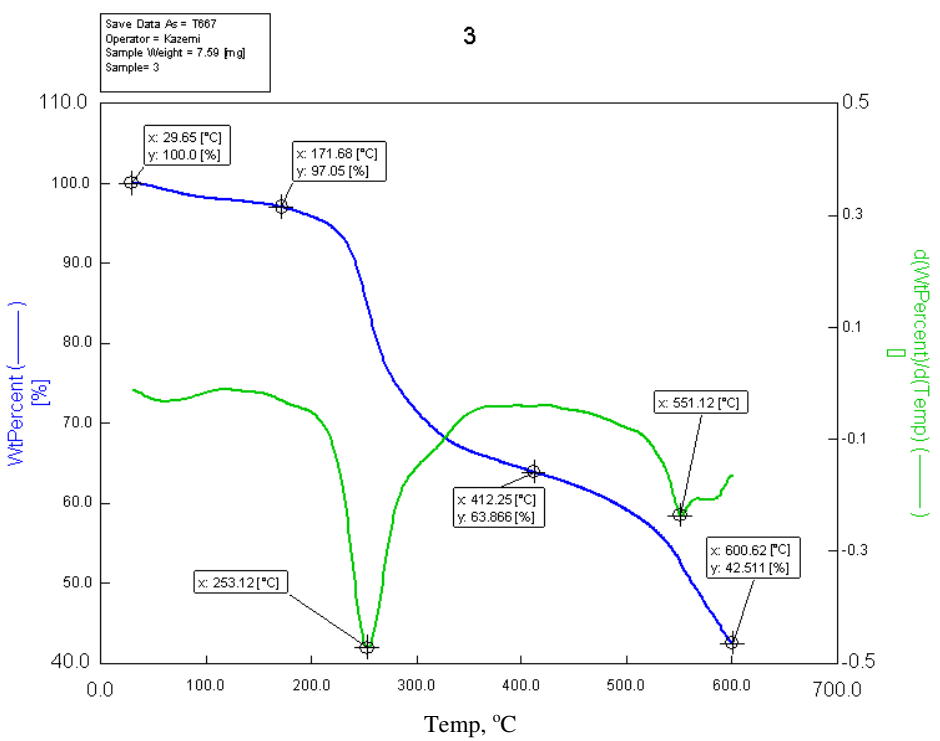

Figure 5. TGA of PA3 


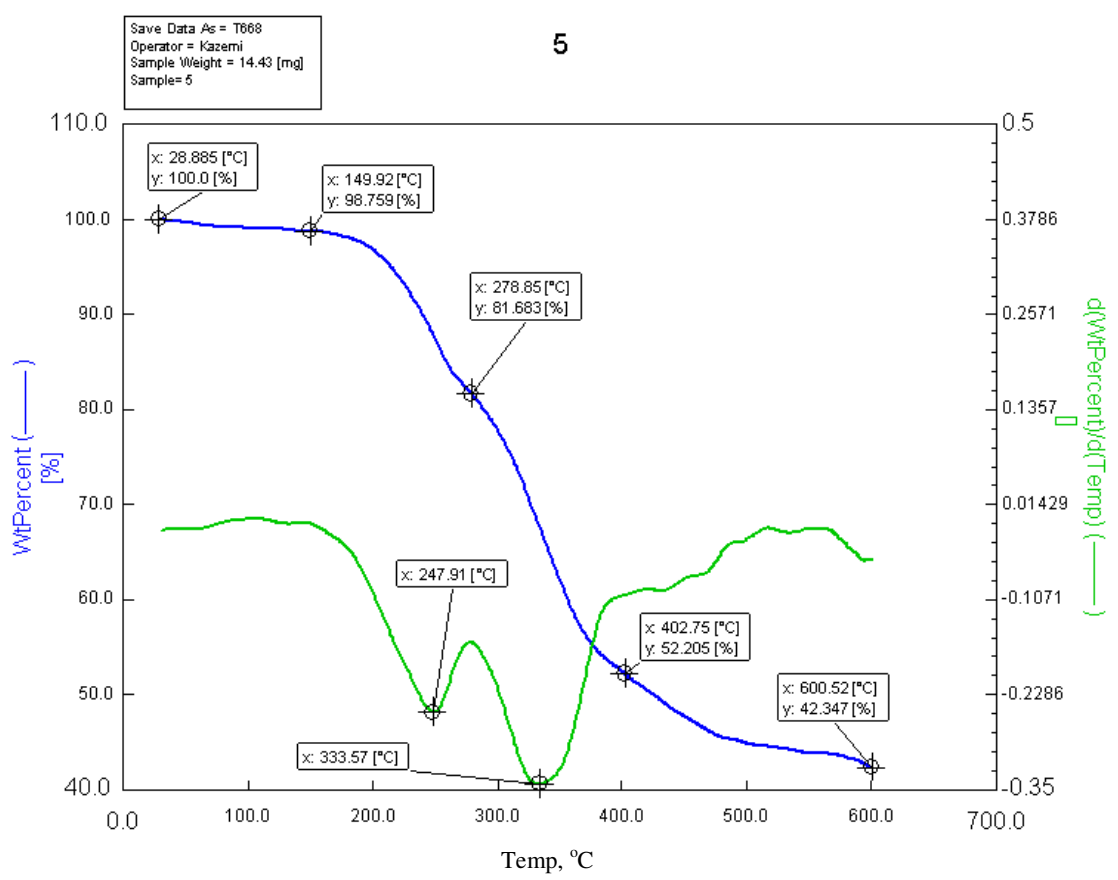

Figure 6. TGA of PA5

\section{Conclusion}

A series of polyamides were prepared from the reaction of diacid chlorides with a diamine $\mathrm{LH}_{6}$. The molar ratio of diacid chloride to the $\mathrm{LH}_{6}$ was 2:2 and the reaction was carried out at ambient temperature for $3 \mathrm{~h}$ under $\mathrm{N}_{2}$ atmosphere. The polyamides were fully characterized and their thermal properties were studied. The introduction of phenyl side groups in structure of the diamine resulted in amorphous polyamides with very good solubility in aprotic solvents such as DMF.

\section{References}

1. Okada A, Kawasumi M, Usuki A, Kojimi Y, Kurauchi T and Kamigato O, Mater Res Symp Proc., 1990, 171, 45.

2. Usuki A, Kojima Y, Kawasumi M, Okada A, Fukushima Y, Kurauchi T and Kamigaito O, J Mater Res., 1993, 8, 1179-1184.

3. Hoffmann B, Kressler J, Stopplemann G, Friedrich C and Kim G-M, Colloid Polym Sci., 2000, 278, 629.

4. Liu X, Wu Q, Zhang Q, Berglund L A and Mo Z, Polym Bull., 2002, 48, 381.

5. Hasegawa N, Okamoto H, Kato M, Usuki A and Sato N, Polymer (Guildf), 2003, 44, 2933.

6. Ayyer R K and Leonov A I, Rheol Acta., 2004, 43, 283-292.

7. Zulfiqar S, Ahmad Z and Sarwar M I, Colloid Polym Sci., 2007, 285(15), 1749-1754.

8. Zulfiqar S, Lieberwirth I and Sarwar M I, Chem Phys., 2008, 344, 202.

9. Sarwar M I, Zulfiqar S and Ahmad Z, J Sol-Gel Sci Technol., 2008, 45, 89.

10. Sarwar M I, Zulfiqar S and Ahmad Z, Colloid Polym Sci., 2007, 285(15), 1733-1739.

11. Zulfiqar S and Sarwar M I, High Perform Polym., 2009. DOI: 10.1177/0954008308089114. 
12. Sarwar M I, Zulfiqar S and Ahmad Z, Polym Int., 2008, 57(2), 292-296.

13. Sarwar M I, Zulfiqar S and Ahmad Z, J Sol-Gel Sci Technol., 2007, 44, 41.

14. Sarwar M I, Zulfiqar S and Ahmad Z, Polym Compos., 2009, 30(1), 95-100.

15. Park Y W and Mark J E, Colloid Polym Sci., 2000, 278, 665.

16. Morgan $\mathrm{P}$ W, Condensation Polymers by Interfacial and Solution Methods (Interscience, New York, 1965).

17. Black W B and Preston J, in Man Made Fibers, Ed., by Mark H, Atlas S M and Cernia E, (Interscience, New York) 1968, 306.

18. Lum F G and Carlston E F, Ind Eng Chem., 1952, 44, 1595.

19. Lum F G and Carlston E F, Ind Eng Chem., 1957, 49, 1239.

20. Beaman R G, Morgan P W, Koller C R and Wittbecker E L, J Polym Sci., 1959, 40(137), 329-336.

21. Shashoua V E and Eareckson W M, J Polym Sci., 1959, 40, 34.

22. Hopff H and Krieger A, Makromol Chem., 1961, 47, 93.

23. Gorton B S, J Appl Polym Sci., 1965, 9, 3753-3758.

24. Bonner W H, U.S. Patent 3,325,342, 1967, assigned to the Du Pont Co.

25. Davis A C and Edwards T E British Patent 1,070,416, 1967, assigned to Imperial Chemical Industries, Ltd.

26. Morgan P W and Kwolek S L, J Polym Sci., 1962, 62, 33-58.

27. Morgan P W and Kwolek S L, Macromolecules, 1975, 8, 104.

28. Catanescu O, Grigoras M, Cololin G, Dobreanu A, Hurduc N and Simionescu C I, Eur Polym J., 2001, 37(2), 2213.

29. Kamal A I and Khalef A A, J Appl Polym Sci., 2000, 77(6), 1218.

30. Khuhawar M Y, Mughal M A and Channar A H, Eur Polym J., 2004, 40, 805-809.

31. Goodwin H A and Bailor J C, J Am Chem Soc., 1961, 83, 2467.

32. Grigoras M, Catanescu C O and Cololin G, Macromol Chem Phys., 2001, 202(2), 2262.

33. Grunes R and Sawondy W, J Chromatogr., 1985, 122, 63.

34. Thomas O I and Andersson M R, Macromolecules, 1998, 31, 2676. 